\title{
Zona Pengembangan Usaha Mikro Kecil dan Menengah (UMKM) Pengolah Makanan di Kota Bekasi
}

\author{
The Development of Food Processing Centers for Micro, Small and Medium Enterprises \\ (MSMEs) Zone in Bekasi City
}

\author{
Fitri Insani $^{1 *}$, Baba Barus ${ }^{2} \&$ Djuara P. Lubis ${ }^{3}$ \\ ${ }^{1}$ Program Studi Ilmu Perencanaan Wilayah, Sekolah Pascasarjana, Institut Pertanian Bogor, Jalan Meranti \\ Kampus IPB Dramaga Bogor 16680, Indonesia; ${ }^{2}$ Departemen Ilmu Tanah dan Sumber Daya Lahan, Fakultas \\ Pertanian, Institut Pertanian Bogor, Jalan Meranti Kampus IPB Dramaga Bogor 16680, Indonesia; \\ ${ }^{3}$ Departemen Sains Komunikasi dan Pengembangan Masyarakat, Fakultas Ekologi Manusia, Institut \\ Pertanian Bogor, Jalan Kamper, Kampus IPB Dramaga 16680, Indonesia; \\ *Penulis korespondensi.e-mail: fitsani@gmail.com \\ (Diterima: 13 September 2020; Disetujui: 4 Desember 2021)
}

\begin{abstract}
Micro, Small and Medium Enterprises (MSMEs) have very significant contribution to the growth and development of the economy of Bekasi City with a total of approximately 203,000 units. The large number of food processing MSMEs in Bekasi City has not been accompanied by the formation of a spatially integrated MSMEs center zoning. This research aims to understand the spatial distribution and the determination of the zones of food processing MSMEs in Bekasi City. The research was conducted in Bekasi City during February-August 2019. Data were obtained through data tracing from related agencies, field observations, and interviews with experts. Analytical methods include Analytical Hierarchy Process (AHP) to determine the weight of each parameter, and Multi Criteria Evaluation (MCE) for determining development centers. Analysis shows that the number of selected MSMEs was 220 samples, with the highest number of MSMEs in Pondok Gede District. Food processing MSME development zones in Bekasi City are divided into three development zones, namely development zone 1, development zone 2, and development zone 3. Development zone 1 and development zone 2 are the best zones located in West Bekasi District, Jatiasih District, and Jatisampurna District. Development Zone 2 consists of North Bekasi District, Medan Satria District, Pondok Gede District, and Pondok Melati District because the two zones are adjacent to Jakarta City. Meanwhile, development zone 3 should receive special attention, consisting of Bantar Gebang District, South Bekasi District, East Bekasi District, Mustika Jaya District, and Rawalumbu District.
\end{abstract}

Keywords: Micro, Small and Medium Enterprises (MSMEs), Multi Criteria Evaluation (MCE), zoning

\section{ABSTRAK}

Usaha Mikro Kecil Menengah (UMKM) memiliki kontribusi yang sangat signifikan terhadap pertumbuhan dan perkembangan perekonomian di Kota Bekasi dengan jumlah sekitar 203,000 unit. Besarnya jumlah UMKM pengolah makanan di Kota Bekasi belum disertai dengan terbentuknya zonasi sentra UMKM yang terintegrasi secara keruangan. Penelitian ini ingin mengetahui persebaran spasial dan penentuan zona sentra UMKM pengolah makanan di Kota Bekasi. Penelitian dilaksanakan di Kota Bekasi yang dimulai bulan Februari-Agustus 2019. Data diperoleh melalui penelusuran data pada instansi terkait, observasi lapangan, dan wawancara 
terhadap ahli. Metode analisis meliputi Analytical Hierarchy Process (AHP) untuk menentukan bobot tiap parameter, dan Multi Criteria Evaluation (MCE) untuk penentuan zona sentra-sentra pengembangan. Hasil analisis menunjukkan jumlah UMKM terpilih sebanyak 220 sampel, dengan UMKM terbanyak terdapat di Kecamatan Pondok Gede. Zona sentra pengembangan UMKM pengolah makanan di Kota Bekasi terbagi menjadi tiga zona sentra pengembangan yaitu zona sentra pengembangan 1 , zona sentra pengembangan 2 , dan zona sentra pengembangan 3 . Zona sentra pengembangan 1 dan zona sentra pengembangan 2 merupakan zona sentra terbaik yang terletak di Kecamatan Bekasi Barat, Kecamatan Jatiasih dan Kecamatan Jatisampurna. Lokasi zona sentra pengembangan 2 di Kecamatan Bekasi Utara, Kecamatan Medan Satria, Kecamatan Pondok Gede, dan Kecamatan Pondok Melati karena kedua zona sentra tersebut bersebelahan dengan Kota Administrasi Jakarta Timur. Sedangkan zona sentra pengembangan 3 yang harus mendapatkan perhatian khusus adalah Kecamatan Bantar Gebang, Kecamatan Bekasi Selatan, Kecamatan Bekasi Timur, Kecamatan Mustika Jaya, dan Kecamatan Rawalumbu.

Kata kunci: Multi Criteria Evaluation (MCE), Usaha Mikro Kecil Menengah (UMKM), zonasi

\section{PENDAHULUAN}

Ditinjau dari segi jumlah unit usaha dan daya serap tenaga kerja Usaha Mikro, Kecil dan Menengah (UMKM) berperan penting dalam pertumbuhan perekonomian Indonesia. Hanya $0.01 \%$ dari total penggiat usaha di Indonesia yang merupakan usaha besar selebihnya adalah penggiat usaha UMKM (BPS dalam Kemenkop dan UMKM, 2010). UMKM mampu menyerap tenaga kerja dengan rata-rata sebesar $97.17 \%$ karena sebagian besar UMKM sifatnya padat karya sehingga dapat meningkatkan serapan tenaga kerja (Sudarno, 2012, Rifa'i, 2013). Namun, untuk meningkatkan penyerapan tenaga kerja dan mengurangi pengangguran maka jumlah UMKM mandiri harus ditingkatkan sehingga dapat meningkatkan penyerapan tenaga kerja, mengurangi pengangguran (Setiawan, 2010).

UMKM memiliki kontribusi yang tinggi terhadap pertumbuhan perekonomian Kota Bekasi. Berdasarkan hasil sensus ekonomi BPS tahun 2016, jumlah UMKM di Kota Bekasi cukup banyak yaitu kurang lebih 203,000 unit UMKM, sebanyak 12,186 merupakan jenis usaha perdagangan pengolahan makanan dan minuman dengan serapan tenaga kerja sebesar 410,000 orang pekerja pada tahun 2016. Jumlah UMKM yang sudah terdaftar sebagai binaan Dinas Koperasi dan Usaha Kecil
Menengah Kota Bekasi sebanyak 2,186 UMKM dari 12,988 UMKM dan mampu menyerap tenaga kerja sebanyak 6,558 orang. Adapun jenis UMKM yang akan diteliti adalah UMKM kategori pengolahan makanan di Kota Bekasi.

Menurut Rizki (2017) wilayah perdagangan dan jasa terpilih karena merupakan wilayah yang memiliki tingkat pertumbuhan baru. Namun salah satu permasalahan yang dihadapi UMKM pengolah makanan di Kota Bekasi yaitu belum terbentuknya zona sentra-sentra UMKM pengolah makanan yang tercantum dalam Rencana Tata Ruang Wilayah (RTRW) ataupun yang terintegrasi secara keruangan (spasial). Hal tersebut terjadi karena tidak terbentuknya spesialisasi dan kerjasama intra-klaster seperti pembelian bahan baku, branding, pengiklanan, distribusi dan ekspor. Spesialisasi produk disebabkan karena besarnya penyerapan tenaga kerja sehingga dapat diketahui subsektor yang potensial (Claudia, 2017). Untuk itu Pemerintah dapat membuat suatu strategi dalam pengembangan UMKM pengolah makanan yang ada di daerah tersebut dengan melihat regulasi yaitu RTRW Kota Bekasi. Strategi tersebut diharapkan untuk menjaga perusahaan agar tetap bertahan sehingga produktivitas UMKM dapat terus ditingkatkan. (Prasetio, 2014). Penelitian ini ingin mengetahui secara 
spasial jumlah UMKM pengolah makanan yang tersebar di Kota Bekasi, dan menentukan zona sentra- sentra UMKM pengolah makanan di Kota Bekasi yang dapat dijadikan alternatif untuk pengembangan wilayah Kota Bekasi.

\section{METODOLOGI}

Penelitian ini mengambil lingkup lokasi penelitian di Kota Bekasi, Provinsi Jawa Barat. Kota Bekasi terdiri dari 12 (dua belas) kecamatan yaitu dengan Luas Wilayah adalah $210.49 \mathrm{Km}^{2} \quad$ [Gambar 1]. Penelitian dilaksanakan sejak bulan Februari sampai dengan Agustus 2019. Lokasi penelitian tersaji pada Gambar 1.

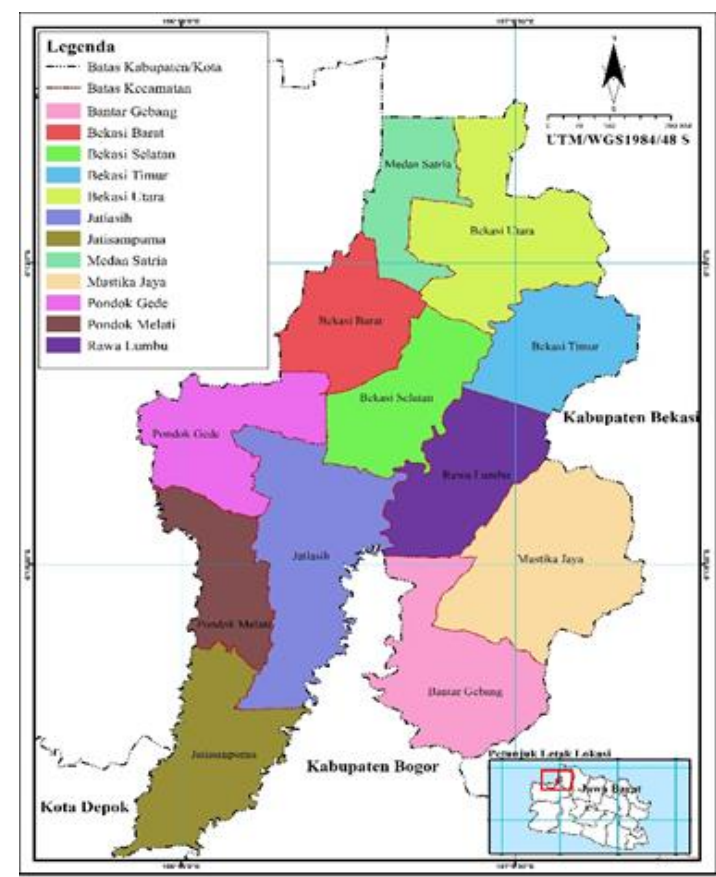

Gambar 1. Peta administrasi Kota Bekasi

Data yang digunakan dalam penelitian merupakan data primer dan data sekunder. Data primer berupa data survei spasial persebaran UMKM pengolah makanan di Kota Bekasi dan data wawancara pakar. Data wawancara pakar digunakan untuk pembobotan analisis AHP yang terdiri dari pelaku UMKM, dinas UMKM, Dinas Perindustrian dan Perdagangan, serta Dinas Ketenagakerjaan. Data Sekunder didapatkan dari instansi-instansi penyaji data dan sumber literatur, artikel serta berbagai sumber lainnya yang berhubungan dengan penelitian. Database UMKM didapat dari Dinas UMKM Kota Bekasi tahun 2018, dan data-data lainnya yang relevan terhadap analisis dalam penelitian.

Populasi penelitian yaitu UMKM pengolah makanan di 12 (dua belas) kecamatan yang diperoleh dari data Dinas UMKM Kota Bekasi Tahun 2018. Selanjutnya akan dipilih sampel dengan menggunakan metode purposive random sampling berdasarkan tempat lokasi pelaku UMKM pengolah makanan di masingmasing kecamatan.

Sebanyak 220 sampel yang harus diteliti diperoleh dengan menggunakan rumus Issac \& Michael (Andriani et al., 2016). Adapun rumus perhitungannya adalah:

$$
n=\frac{\lambda^{2} \times \mathrm{N} \times \mathrm{P} \times \mathrm{Q}}{\mathrm{d}^{2} \times(\mathrm{N}-1)+\lambda^{2} \times \mathrm{P} \times \mathrm{Q}}
$$

$$
\begin{aligned}
& \text { Keterangan : } \\
& \mathrm{n}= \text { jumlah sampel } \\
& \mathrm{N}= \text { jumlah populasi } \\
& \lambda^{2}= \text { nilai Chi Square, dengan } \mathrm{dk}=1 \text { dan } \\
& \text { taraf kesalahan } 5 \text { persen, sehingga } \\
& \text { diperoleh nilai } \lambda 2=3.84 \text { (tabel chi } \\
& \text { square) } \\
& \mathrm{P}= \begin{array}{l}
\text { proporsi dalam populasi }=0.50 \\
\text { (mendekati kurva distribusi normal) }
\end{array} \\
& \mathrm{Q}= 1-\mathrm{P}=1-0.50=0.50 \\
& \mathrm{~d}= \text { ketelitian atau tingkat akurasi } \\
&\text { persen }=0.05)
\end{aligned}
$$

Adapun penentuan jumlah sampel dari masing-masing kelurahan yang akan diteliti menggunakan rumus sebagai berikut (Narimawati, 2007):

\section{$n \mathbf{n}=\mathbf{N i} / \mathbf{N} \times \mathbf{n}$}

\section{Keterangan:}

ni = Besarnya sampel pada strata ke-i

$\mathrm{Ni}=$ Besarnya populasi pada strata ke-i

$\mathrm{N}=$ Besarnya populasi keseluruhan

$\mathrm{N} \quad=$ Besarnya ukuran sampel

Setelah total keseluruhan sampel diketahui selanjutnya dilakukan survei lapangan untuk mengecek data keberadaan pelaku UMKM pengolah makanan di Kota Bekasi 
dengan tujuan untuk mengetahui atau menduga posisi geografis dan persebaran pelaku UMKM pengolah makanan. Pada penelitian ini survei lapangan dilakukan dengan bantuan data berupa daftar alamat UMKM pengolah makanan di Kota Bekasi.

\section{Penentuan Zonasi Sentra Pengembangan Wilayah UMKM Pengolah Makanan}

Penentuan zonasi sentra pengembangan UMKM dimaksudkan untuk dapat mendorong terbentuknya kelompok jaringan usaha yang terintegrasi dan saling terkait secara spasial pada suatu wilayah. Hal tersebut untuk dapat meningkatkan efektivitas dan efisiensi baik dari segi penjualan maupun penyerapan (tenaga kerja dan bahan baku). Pembentukan zona sentra-sentra tersebut diharapkan dapat mendorong terjadinya peningkatan spesialisasi dan kerjasama intra-klaster seperti pembelian bahan baku, branding, pengiklanan, distribusi dan ekspor. Zonasi sentra tersebut diharapkan menjadi klaster aktif dan seiring waktu dapat berkembang menjadi klaster industri maju. Parameter yang digunakan dalam penentuan zona sentra pengembangan UMKM yaitu menggunakan 5 parameter meliputi; sebaran UMKM, jumlah tenaga kerja, tujuan pemasaran, kemitraan, dan penerapan standar K3. Unit analisis yang digunakan adalah masing-masing wilayah kecamatan di Kota Bekasi. Tiap-tiap parameter tersebut kemudian dihitung nilai indeksnya. Penentuan nilai tiaptiap interval nilai indeks yaitu dengan rumus sebagai berikut:

Interval $=$ (Nilai Maksimum-Nilai Minimum)/Jumlah Kelas

Nilai maksimum diperoleh dari nilai indeks tertinggi yang dihasilkan, sementara nilai minimum diperoleh dari nilai indeks terendah yang dihasilkan, adapun jumlah kelas adalah jumlah kelas/kategori yang diinginkan. Metode MCE (Multi Criteria Evaluation) digunakan dalam perhitungan indeks zonasi sentra pengembangan UMKM pengolah makanan di Kota Bekasi. Dalam memutuskan masalah-masalah komplek multikriteria seperti aspek kualitatif dan atau kuantitatif dapat dilakukan dengan metode MCE (Suriani et al., 2019) dengan menetapkan tujuan dan kriteria (Santosa et al., 2014). Penggunaan metode MCE dalam penentuan bobot didasarkan pada parameter yang didapat dari hasil wawancara para pakar sehingga dapat dihasilkan parameter yang lebih sesuai (Iswandi et al., 2017).

Analisis MCE dilakukan melalui integrasi data spasial (administrasi kecamatan) dengan penilaian pakar dan memberikan bobot pada masing-masing parameter secara spasial (Pratomo, 2009). Pembobotan untuk tiap-tiap parameter diperoleh dengan metode AHP agar masalah multi faktor/multi aspek ataupun multi kriteria yang kompleks menjadi suatu hierarki/level dapat teruraikan (Saaty, 1993). Tahapan operasional AHP dalam penelitian ini mengacu pada (Yusuf et al., 2018):

1. Menyusun struktur hierarki, meliputi; goal, aspek, tujuan dan alternatif

2. Mendefinisikan fokus/tujuan/goal, yakni; alternatif wilayah pengembangan UMKM pengolah makanan di Kota Bekasi.

3. Mendefinisikan kriteria meliputi; tenaga kerja, penerapan standar $\mathrm{K} 3$, pemasaran produk, kemitraan.

4. Membuat matriks perbandingan berpasangan (pairwise comparison).

5. Interpretasi output yaitu dengan melihat nilai persentase yang diperoleh dari setiap variabel/elemen dengan nilai total $100 \%$ atau 1 (satu).

Hasil persepsi masing-masing pakar merupakan input utama dalam metode AHP sehingga diperoleh hasil berupa pembobotan dari masing-masing parameter (Hidayah et al., 2017). Hasil tersebut diperoleh dari wawancara dan kuesioner para pakar diolah dengan AHP untuk mendapatkan bobot dari masing-masing parameter sehingga dapat dikelompokkan berdasarkan nilai indeks dan dianalisis dengan metode MCE untuk mengetahui lokasi zona sentra pengembangan berdasarkan kategori. 
Hasil analisis yang diperoleh dikategorikan ke dalam 3 zona sentra pengembangan yaitu zona sentra pengembangan 1 , zona sentra pengembangan 2 dan zona sentra pengembangan 3. Penetapan kategori tiap-tiap zona sentra pengembangan diperoleh dari hasil perkalian bobot dan skor tiap-tiap parameter dan kriteria. Penentuan nilai interval mengacu pada nilai tengah (median) dari hasil perkalian bobot dan skor tersebut sesuai rumus dasar penentuan interval namun dibuat secara subjektif agar didapat interval yang proporsional. Selengkapnya disajikan pada Tabel 1.

Tabel 1. Penentuan nilai interval dalam analisis sentra-sentra pengembangan UMKM

\begin{tabular}{ll}
\hline Penentuan Interval & Kategori \\
\hline Nilai medium+(Nilai & Zona Sentra \\
maksimum-nilai minimum)/2 & Pengembangan 1 \\
\hline Nilai medium+(Nilai median- & Zonasi Sentra \\
nilai minimum)/2 & Pengembangan 2 \\
\hline $\begin{array}{l}\text { Nilai minimum+(Nilai median- } \\
\text { nilai minimum)/2 }\end{array}$ & Zonasi Sentra \\
\hline
\end{tabular}

\section{HASIL DAN PEMBAHASAN}

\section{Persebaran UMKM Pengolah Makanan Secara Spasial}

Persebaran UMKM diperoleh dari survei lapangan dengan mengacu pada data sekunder yang diperoleh dari Dinas Koperasi dan UMKM Kota Bekasi. Jumlah lokasi UMKM yang disurvei yaitu sebanyak 220 UMKM yang tersebar merata di seluruh wilayah Kota Bekasi. Hasil survei tersebut kemudian diintegrasikan ke dalam SIG sehingga menghasilkan peta persebaran UMKM di Kota Bekasi [Gambar 2].

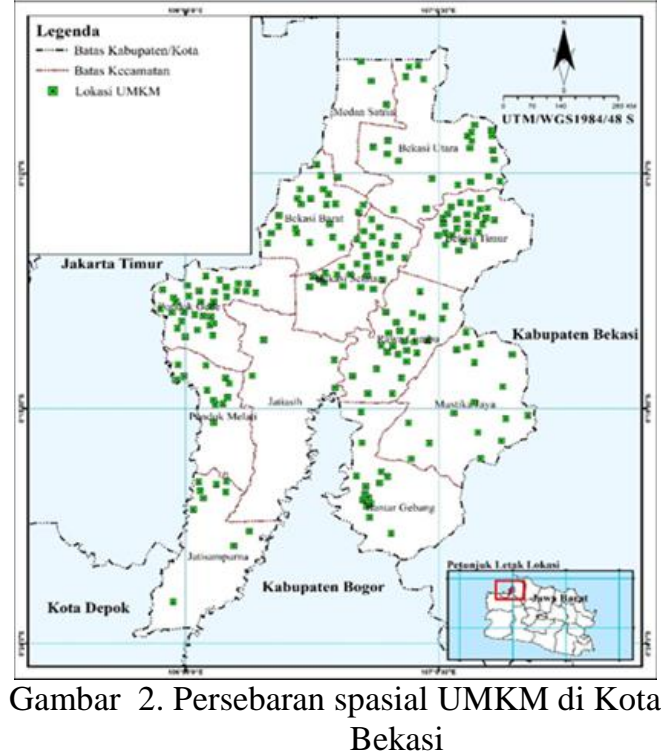

\section{Zona Sentra Pengembangan UMKM Pengolah Makanan}

Hasil penilaian pakar dalam penentuan bobot terhadap parameter penentu disajikan pada Gambar 3. Nilai bobot tertinggi berdasarkan penilaian pakar adalah tujuan pemasaran (0.366), sedangkan yang terendah yaitu penerapan standard $\mathrm{K} 3$ dan jumlah tenaga kerja dengan masing-masing nilai bobot (0.136). Dalam penelitian ini, penilaian pakar memiliki nilai inconsistency sebesar 0.04 yang berarti pakar cukup konsisten dalam memberikan penilaian karena kurang dari 0.1 (Marimin \& Maghfiroh, 2010).

Hasil analisis penentuan indeks dan skor tiap-tiap parameter yang digunakan dalam menentukan zona sentra-sentra pengembangan tersaji pada Tabel 2.

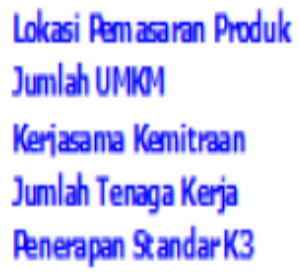

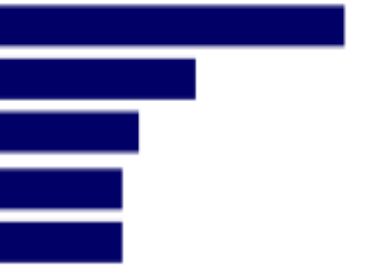

Gambar 3. Penilaian pakar 
Tabel 2. Kriteria dalam penentuan zonasi sentra pengembangan UMKM

\begin{tabular}{llll}
\hline Parameter & Bobot & Kriteria & Skor \\
\hline Sebaran UMKM & 0.211 & Indeks Sebaran UMKM & Nilai Indeks \\
\hline Tenaga Kerja & 0.136 & Indeks Tenaga Kerja & Nilai Indeks \\
\hline Tujuan Pemasaran & 0.366 & Indeks Tujuan Pemasaran & Nilai Indeks \\
\hline Kemitraan & 0.152 & Indeks Kemitraan & Nilai Indeks \\
\hline Penerapan Standar K3 & 0.136 & Indeks Penerapan K3 & Nilai Indeks \\
\hline
\end{tabular}

Tingkat persebaran UMKM pengolah makanan di Kota Bekasi dikategorikan ke dalam 3 kategori kerapatan yaitu rendah, sedang dan tinggi [Tabel 3]. Parameter kerapatan UMKM yang termasuk ke dalam kategori kerapatan sedang dan tinggi mengindikasikan adanya pemusatan aktivitas UMKM dalam satu cakupan area terbatas [Gambar 4].

Terdapat 22 UMKM di Kecamatan Bekasi Barat dengan luas kerapatan sebesar 849.07 ha dan luas wilayah Kecamatan Bekasi Barat seluas 1,402.59 ha sehingga dihasilkan index tertinggi sebesar 0.29. Mayoritas dari UMKM tersebut adalah usaha pengolah makanan jenis Cake $n$ Bakery. Sementara itu sebanyak 32 UMKM yang terdapat di Kecamatan Pondok Gede termasuk ke dalam kategori kerapatan sedang karena memiliki luas kerapatan sebesar 908 ha dan luas wilayah sebesar 1,659 ha sehingga dihasilkan indeks kategori sedang sebesar 0.14 mayoritas dari UMKM tersebut adalah usaha pengolah makanan jenis kue basah. Untuk kategori terendah dengan indeks sebesar 0.01 adalah Kecamatan Jatiasih dengan jumlah UMKM sebanyak 5 UMKM dengan jenis produk bervariasi, luas wilayah sebesar 2,570.49 ha dan luas sebaran sebesar 43.73 ha.

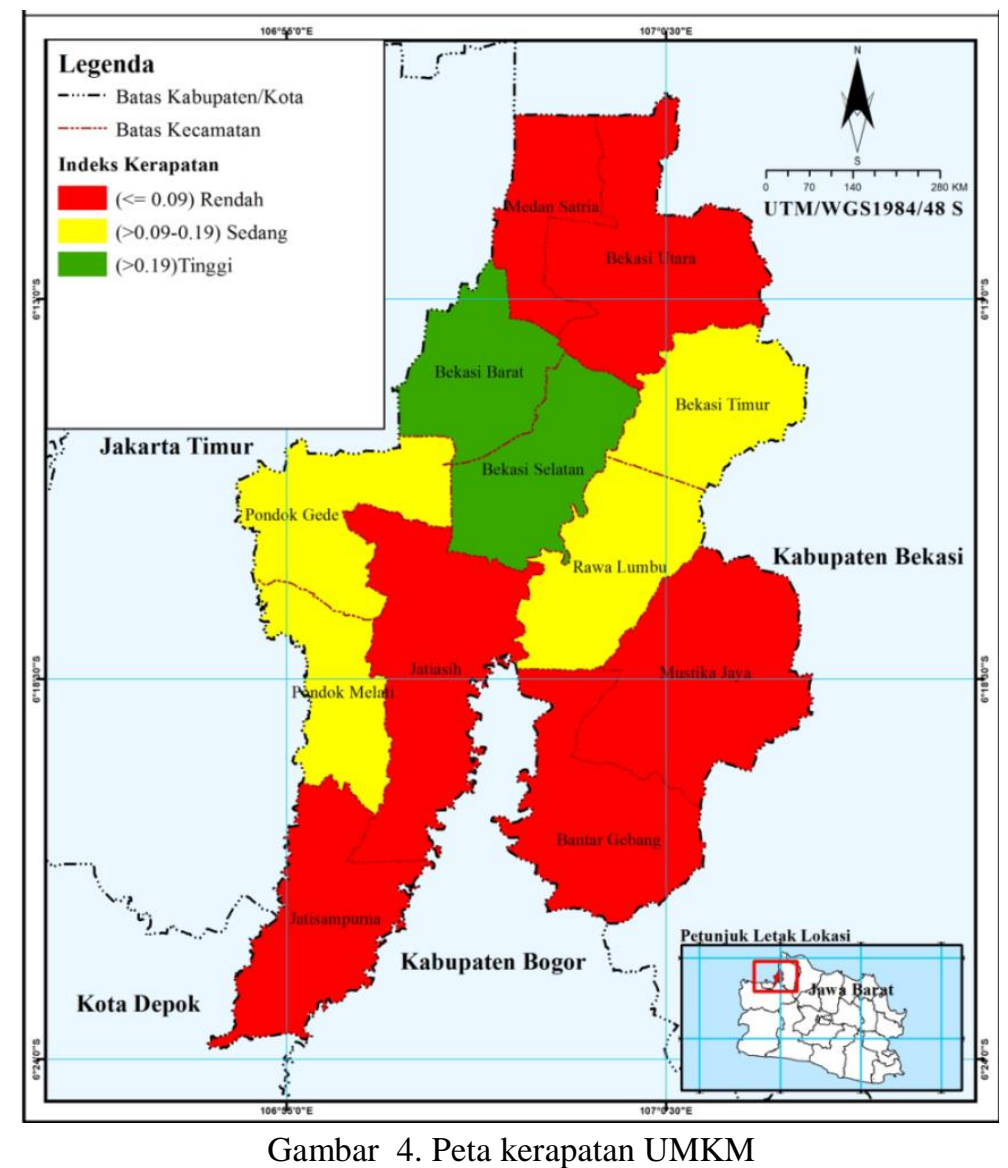


Tabel 3. Indeks kerapatan UMKM

\begin{tabular}{|c|c|c|c|c|c|c|}
\hline \multirow{2}{*}{ No. } & \multirow{2}{*}{ Kecamatan } & \multirow{2}{*}{$\begin{array}{l}\text { Jumlah } \\
\text { UMKM }\end{array}$} & \multirow{2}{*}{ Kategori } & \multirow{2}{*}{ Indeks } & \multicolumn{2}{|l|}{ Luas } \\
\hline & & & & & ha & $\%$ \\
\hline 1 & Bantar Gebang & 14 & Rendah & 0.08 & 2,037 & 9 \\
\hline 2 & Bekasi Utara & 21 & Rendah & 0.08 & 2,467 & 11 \\
\hline 3 & Jatiasih & 5 & Rendah & 0.01 & 2,570 & 12 \\
\hline 4 & Jatisampurna & 10 & Rendah & 0.07 & 1,869 & 9 \\
\hline 5 & Medan Satria & 9 & Rendah & 0.01 & 1,095 & 5 \\
\hline 6 & Mustika Jaya & 17 & Rendah & 0.02 & 2.672 & 12 \\
\hline \multicolumn{2}{|c|}{ Jumlah } & & & & 12,710 & 59 \\
\hline 7 & Bekasi Timur & 26 & Sedang & 0.12 & 1,484 & 7 \\
\hline 8 & Pondok Gede & 32 & Sedang & 0.14 & 1,659 & 8 \\
\hline 9 & Pondok Melati & 11 & Sedang & 0.12 & 1,178 & 5 \\
\hline 10 & Rawa Lumbu & 24 & Sedang & 0.12 & 1,710 & 8 \\
\hline \multicolumn{2}{|c|}{ Jumlah } & & & & 6,033 & 28 \\
\hline 11 & Bekasi Selatan & 29 & Tinggi & 0.20 & 1,538 & 7 \\
\hline 12 & Bekasi Barat & 22 & Tinggi & 0.29 & 1,403 & 6 \\
\hline \multicolumn{2}{|c|}{ Jumlah } & & & & 2,941 & 14 \\
\hline \multicolumn{2}{|c|}{ Jumlah Keseluruhan } & & & & 21,684 & 100 \\
\hline
\end{tabular}

Tenaga kerja memiliki pengaruh yang cukup besar dalam hal pembentukan zona sentra-sentra UMKM. Kinerja tenaga kerja dapat meningkatkan hasil output dalam pekerjaan yang dipengaruhi oleh tinggi rendahnya kualitas dari seorang tenaga kerja yang akan mempengaruhi produktivitasnya (Adhadika \& Pujiyono, 2014). Seperti yang diungkapkan Kusmayanti \& Tyas (2016) dengan adanya UMKM pengolah pangan dapat meningkatkan perekonomian karena dapat menyerap tenaga kerja sebesar $3.71 \%$ atau sekitar 3-4 orang tenaga kerja. Hasil analisis indeks tenaga kerja di Kota Bekasi dikelompokkan ke dalam 3 kategori yaitu rendah, sedang, dan tinggi [Tabel 4]. Hasil analisis indeks tenaga kerja di Kota Bekasi kategori tinggi tersebar di Kecamatan Jatiasaih dan Kecamatan Pondok Melati dengan nilai indeks >0.10 [Gambar 5]. Wilayah yang termasuk ke dalam kategori ini memiliki jumlah rata-rata tenaga kerja pada tiap-tiap UMKM yang relatif memadai jika dibandingkan dengan jumlah keseluruhan tenaga kerja UMKM dalam agregat wilayah Kecamatan.

Kategori sedang tersebar pada 4 kecamatan meliputi Kecamatan Bantar Gebang, Kecamatan Jatisampurna, Medan Satria, dan Kecamatan Mustika Jaya. Pada kategori ini sudah ada pelaku UMKM yang menghasilkan produk tertentu dengan banyak permintaan dikarenakan produk tersebut memiliki ciri khas baik rasa ataupun bentuk produknya.

Pada kategori rendah dimaksudkan bahwa pelaku UMKM dalam menjalankan usahanya tidak memerlukan banyak tenaga kerja karena produk yang dihasilkan bersifat umum dan dapat dikerjakan dengan mudah oleh siapa pun tanpa perlu adanya keahlian tertentu yang harus dimiliki meliputi Kecamatan Bekasi Barat, Bekasi Selatan, Bekasi Timur, Bekasi Utara, Pondok Gede, dan Kecamatan Rawa Lumbu. 


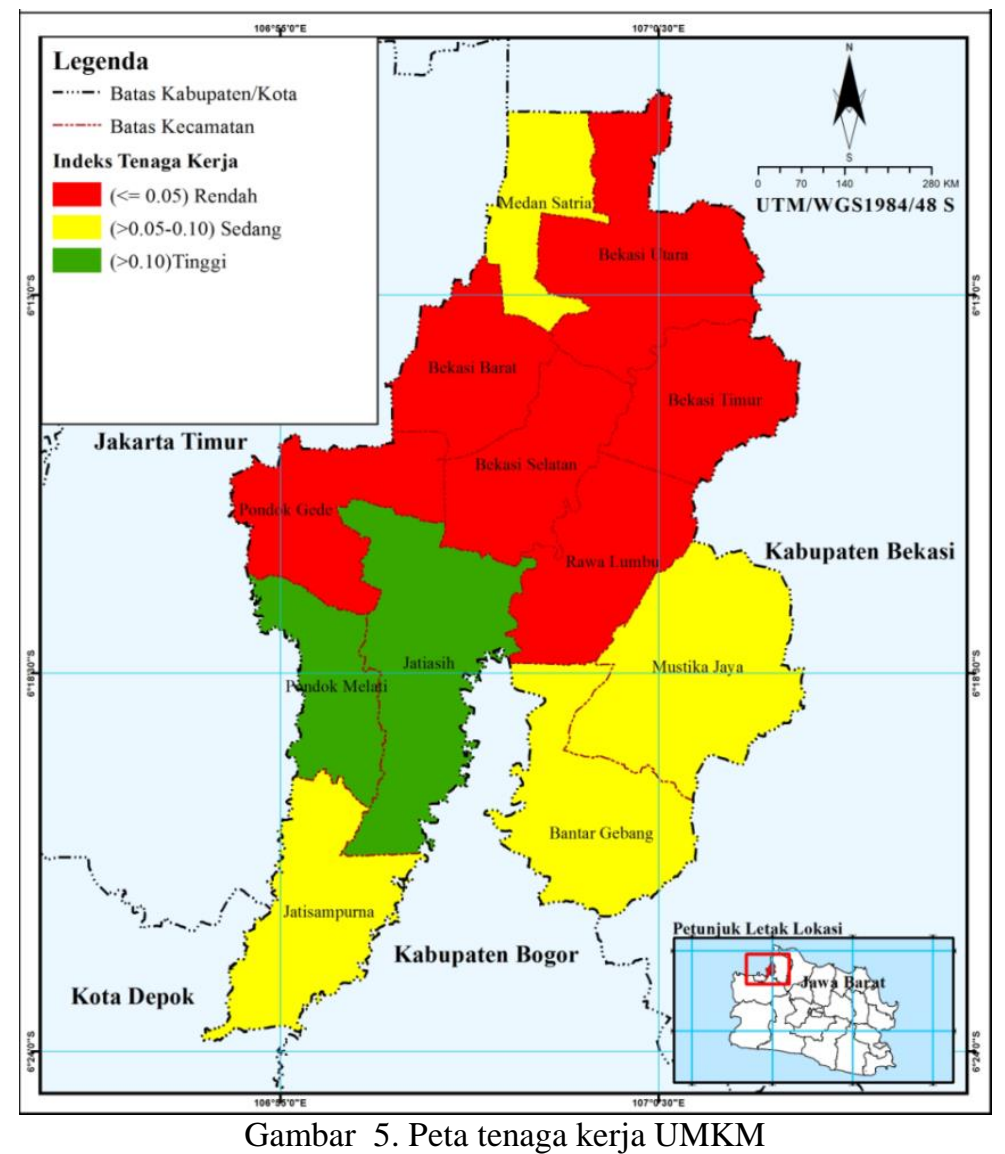

Tabel 4. Indeks tenaga kerja UMKM

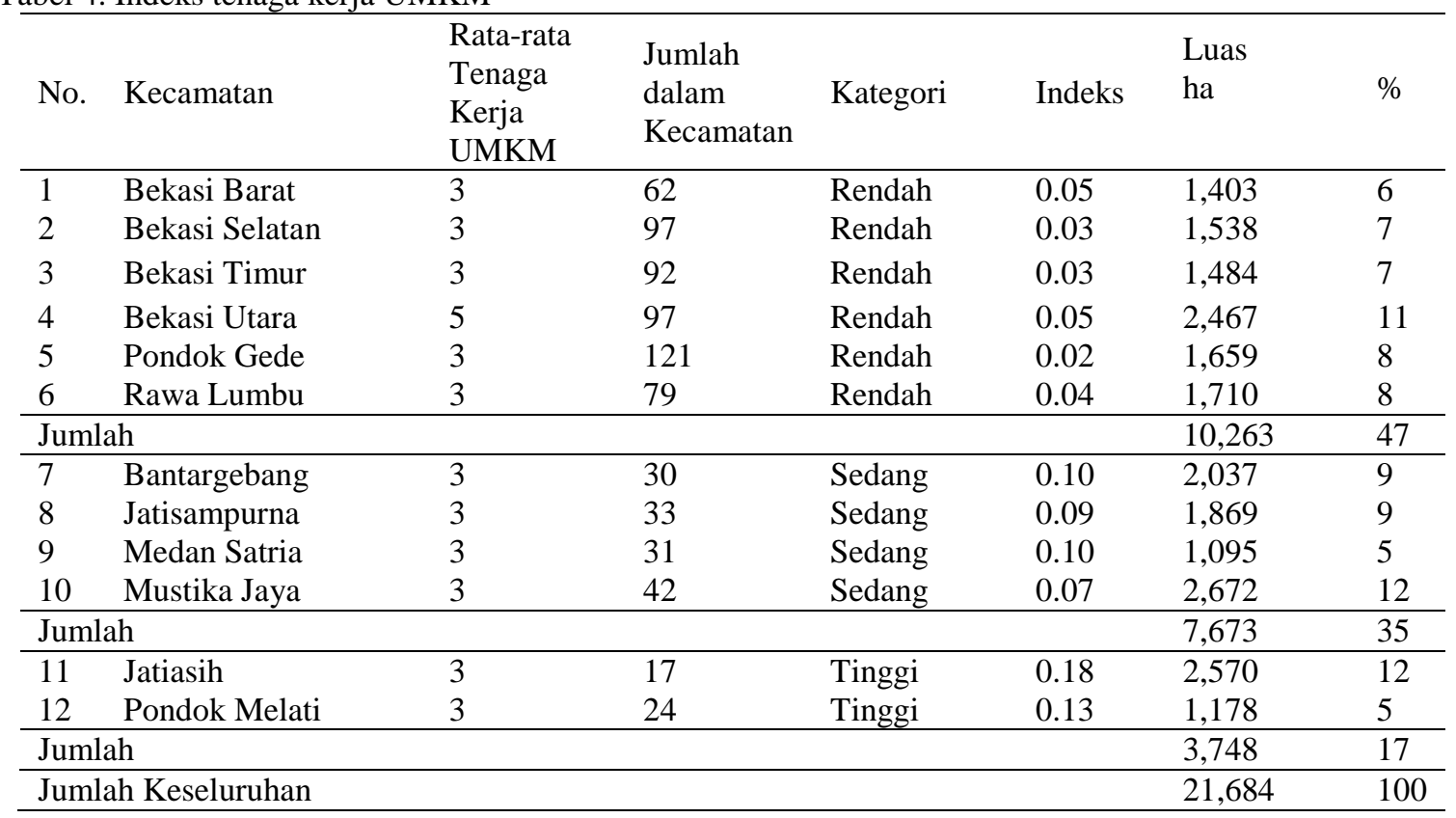

Tujuan pemasaran yang menjadi tolak ukur dimana suatu wilayah dapat dijangkau pasarnya. Semakin besar cakupan wilayahnya semakin mendukung untuk pengembangan zona sentra-sentra UMKM.
Menurut Setyanto et al. (2015) dengan melakukan inovasi produk dan menerapkan modal sosial serta memperbanyak jaringan bisnis maka UMKM dapat dikembangkan. Sehingga hal tersebut menjadikan pemasaran sangat berperan dalam menentukan 
keberlangsungan suatu UMKM, karena sangat terkait dengan omzet perusahaan yang dapat dihasilkan. Semakin luas jangkauan pemasarannya berarti omzet juga akan meningkat. Hasil analisis indeks tujuan pemasaran dibagi ke dalam 3 kategori yaitu kurang luas (lokal), cukup luas (regional) dan sangat luas (nasional) [Tabel 5]. Berdasarkan Tabel tersebut menunjukkan bahwa wilayahwilayah Kecamatan di Kota Bekasi masih dominan memiliki tujuan pemasaran cukup luas yaitu mencakup area di seputaran wilayahwilayah di dalam Kota Bekasi dan daerah perbatasannya.

Wilayah kategori tujuan pemasaran kurang luas yaitu yang memiliki nilai indeks tujuan pemasaran sebesar $<=0,06$ meliputi Kecamatan Bekasi Barat, Bekasi Selatan, Bekasi Timur, Bekasi Utara, Pondok Gede, dan
Rawa Lumbu. Kecamatan tersebut berada di pusat Kota Bekasi sehingga untuk menjual produknya banyak pelaku UMKM hanya memasarkan di pusat kota karena di sana merupakan lokasi strategis dan terpusat yang terdiri dari tempat perbelanjaan terbesar di Bekasi.

Parameter tujuan pemasaran yang termasuk ke dalam kategori sangat luas memiliki nilai indeks sebesar $>0.12$ meliputi Kecamatan Jatiasih, Jatisampurna, dan Medan Satria dengan produk seperti rendang sapi, dendeng, katering dan sejenisnya sehingga hasil produknya tidak terbatas hanya di Kota Bekasi atapun Kota/Kabupaten terdekat saja. Wilayah yang termasuk ke dalam kategori ini adalah yang memiliki tujuan pemasaran rata-rata UMKM nya yaitu pada tingkatan lokal, regional maupun nasional [Gambar 6].

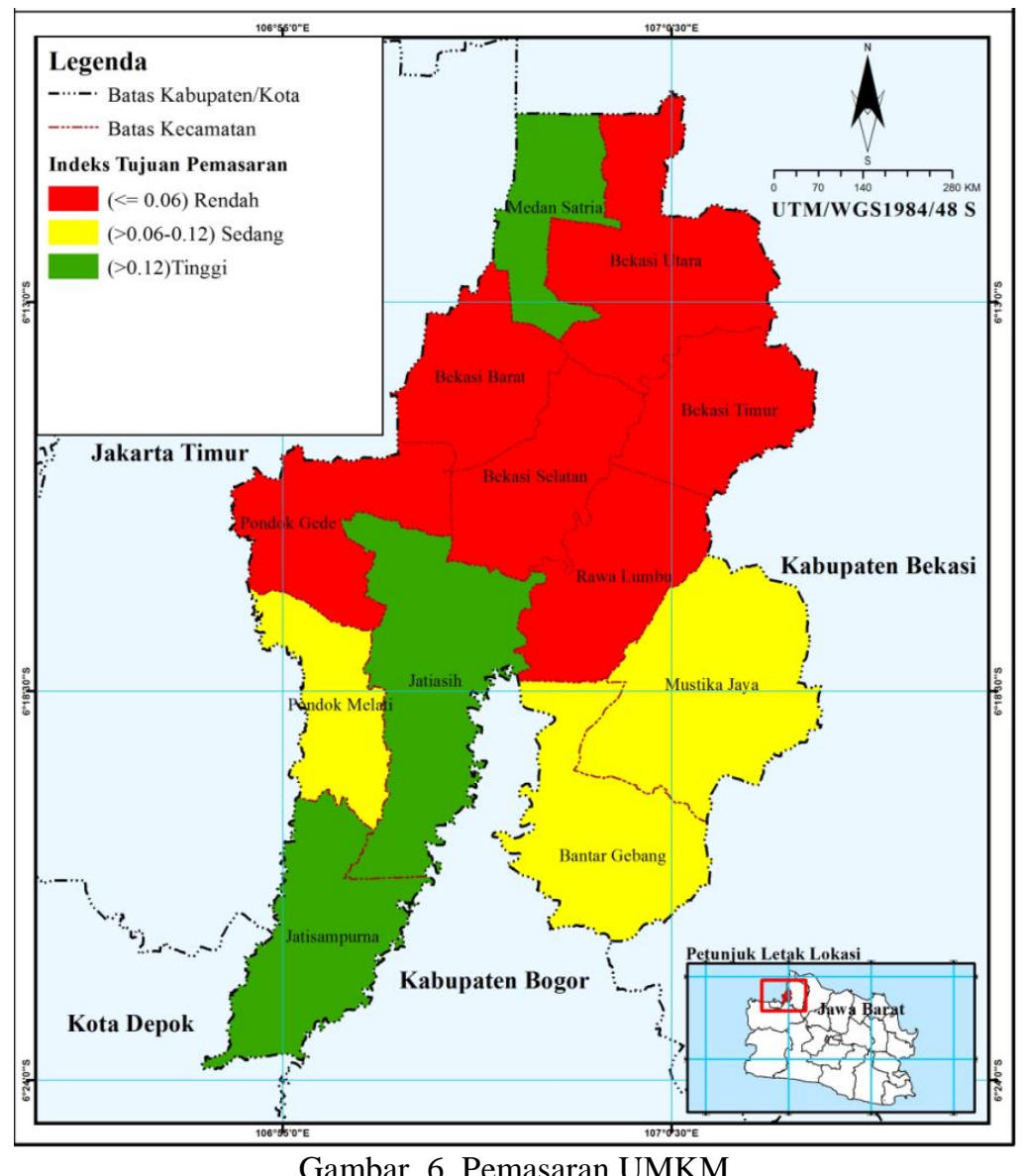


Tabel 5. Indeks pemasaran UMKM

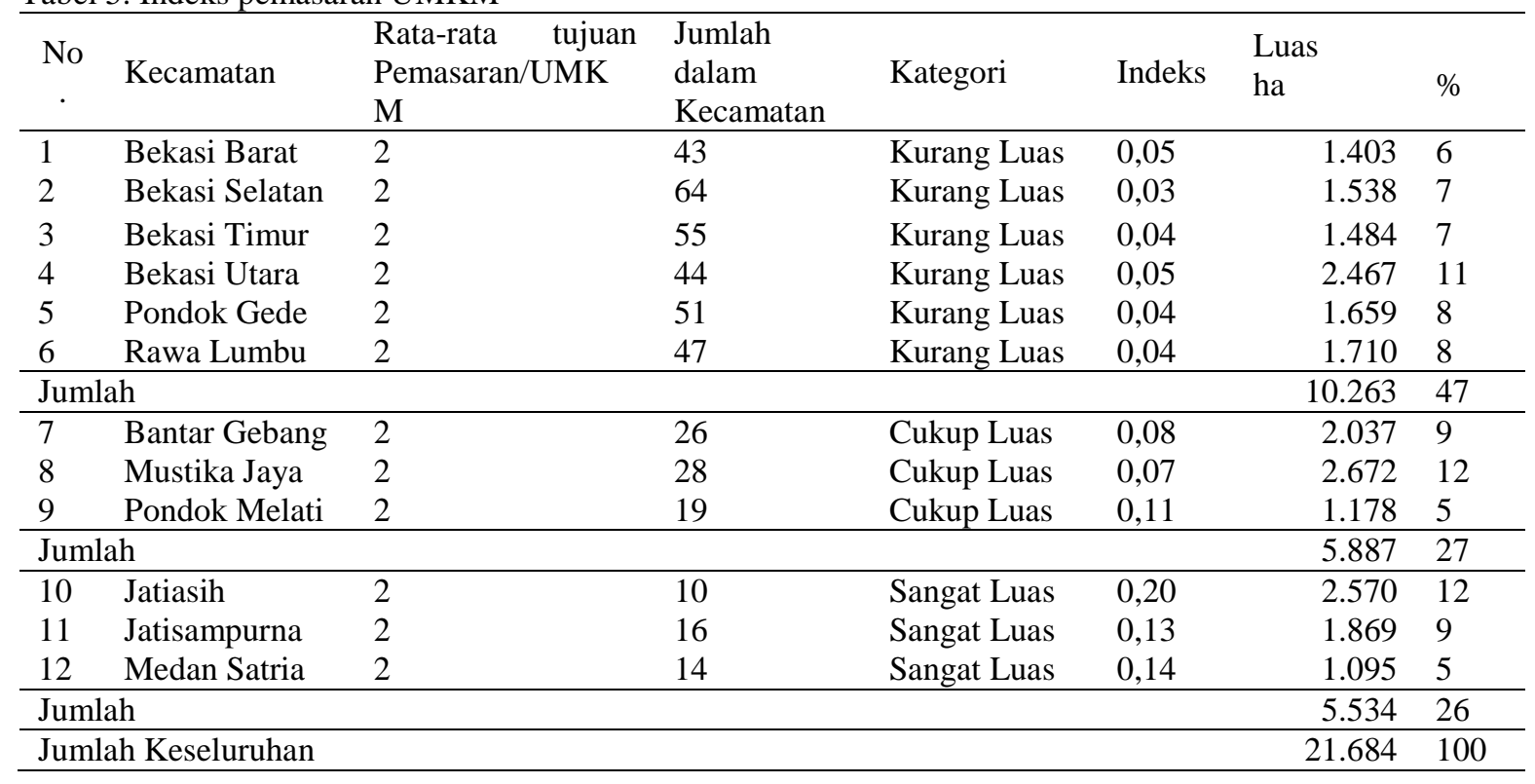

Parameter kemitraan menjelaskan seberapa besar kemitraan yang terbentuk antara tiap-tiap UMKM yang terdapat dalam masingmasing Kecamatan. Kemitraan tersebut dapat berupa kerjasama dengan konsumen individu, swasta, maupun pemerintah. Selain itu, untuk mengembangkan teknologi UMKM dapat melakukan kerjasama dengan asosiasi-asosiasi UMKM dengan perguruan tinggi atau pusatpusat penelitian (Harsono, 2012). Semakin tinggi indeks kemitraannya semakin besar kemitraan yang terbentuk.

Hasil analisis menunjukkan parameter kemitraan yang termasuk ke dalam kategori kemitraan tinggi memiliki nilai indeks sebesar $>0.06$ meliputi Kecamatan Jatiasih, Jatisampurna, Medan Satria, Mustika Jaya, dan Kecamatan Pondok Melati. Wilayah yang termasuk ke dalam kategori ini yaitu yang ratarata UMKM nya telah bermitra dengan pemerintah pada level lokal dan swasta pada level lokal maupun regional [Tabel 6].
Kemitraan dengan kategori kurang bermitra paling dominan di Kecamatan Pondok Gede dengan hasil produk berupa makanan cemilan kaki lima seperti molen, pisang goreng, pastel, donat, gemblong, dll. sehingga cukup sulit untuk menarik pihak lain untuk bekerja sama dalam hal penjualan ataupun pembiayaan.

Kategori kemitraan sedang memiliki nilai indeks sebesar >0,03-0.06 meliputi Kecamatan Bantar Gebang, Bekasi Barat, Bekasi Selatan, Bekasi Timur, Bekasi Utara, dan Kecamatan Rawa Lumbu. Wilayah yang termasuk ke dalam kemitraan sedang memiliki tingkat kemitraan yang mulai beragam tidak hanya pada konsumen individu namun juga sudah terbentuk kerjasama dengan pihak swasta pada level lokal seperti indomaret, alfamart, dan lainnya karena mayoritas produk yang dijual berupa makanan yang sifatnya tahan lama seperti cookies atau snack. Wilayah yang termasuk ke dalam kategori ini dapat terlihat pada Gambar 7. 


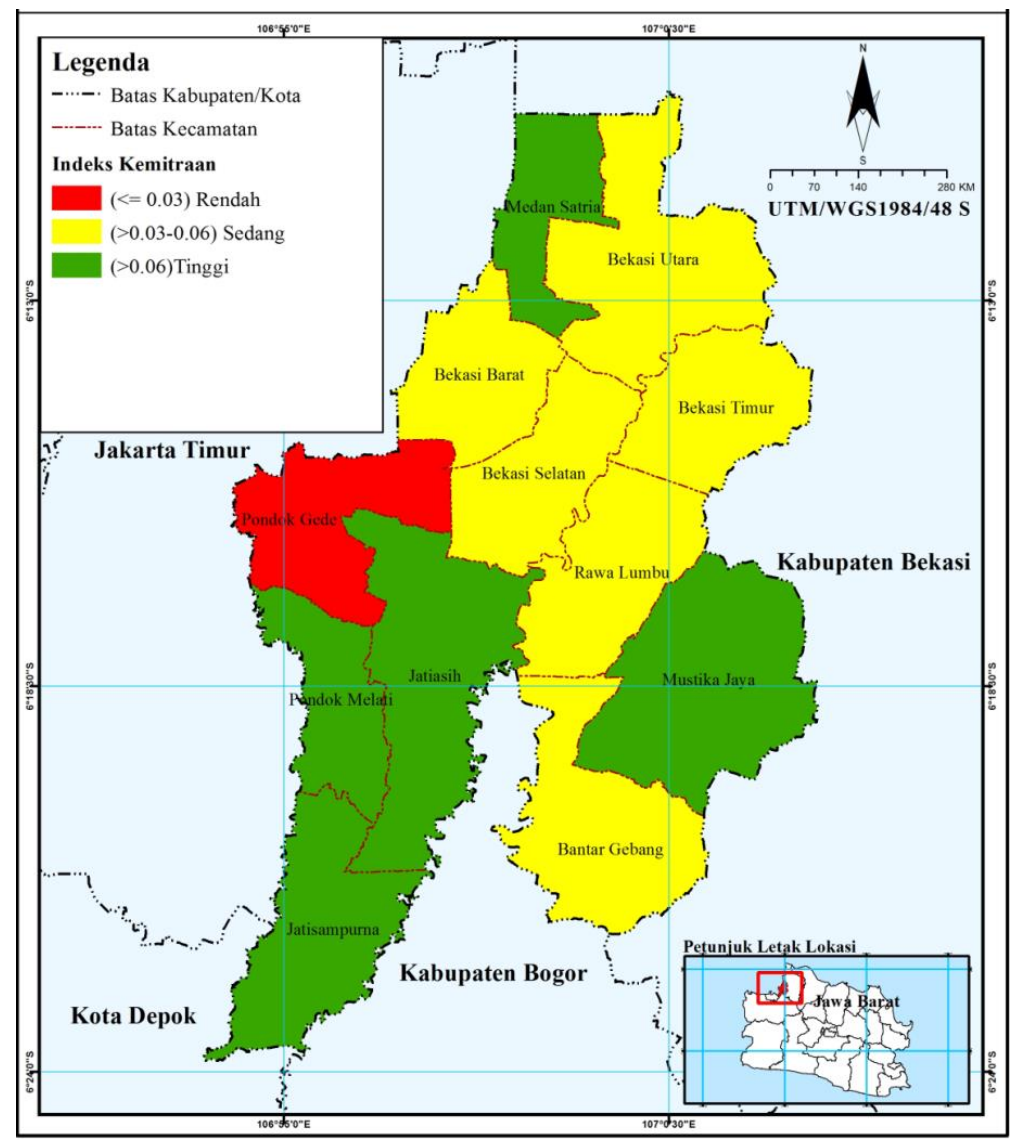

Gambar 7. Index kemitraan UMKM

Tabel 6. Indeks kemitraan UMKM

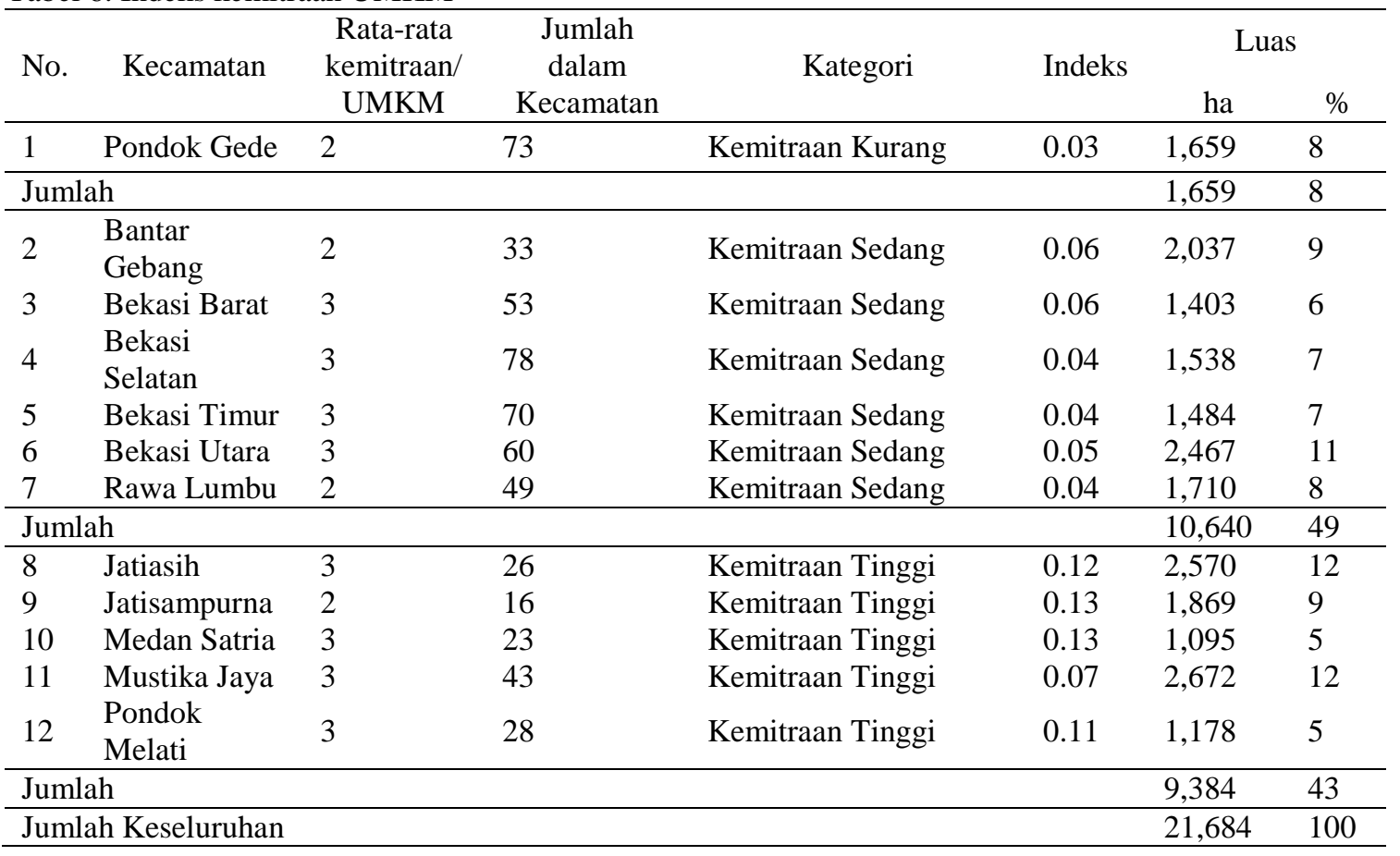

Kesehatan dan keselamatan kerja dari tiap-tiap tenaga kerja akan mendorong produktivitas dari tenaga kerja tersebut, karena adanya jaminan kesehatan dan rasa aman dalam melakukan proses produksi. Penerapan standar Kesehatan dan Keselamatan Kerja (K3) dapat menjadi ukuran kualitas dari suatu usaha termasuk UMKM. Semakin mengikuti standar 
berarti semakin modern UMKM tersebut. Parameter penerapan standar K3 hanya terdiri dari kategori rendah dan sedang, hal tersebut karena tidak ditemukan wilayah yang telah menerapkan indikator K3 yang dipersyaratkan [Tabel 7].

Parameter penerapan standard K3 yang termasuk ke dalam kategori sedang yaitu dengan nilai indeks sebesar 0.50 meliputi Kecamatan Bekasi Barat, Bekasi Utara, Jatisampurna dan Pondok Gede. Wilayah yang termasuk ke dalam kategori ini yaitu yang mengikuti 2 dari 4 standar yang dipersyaratkan yaitu bangunan usaha yang bersih, rapi, tertata, tidak becek dan luas, serta tata laksana kerumah tanggaan (memisahkan alat, perkakas yang digunakan dan menetapkan serta melaksanakan prosedur kebersihan alat), Kecamatan tersebut mayoritas telah memiliki produk UMKM yang sudah dikenal pasar seperti cathering, cake bakery, abon ikan, dan frozen food.

Kecamatan Bantar Gebang, Bekasi Selatan, Bekasi Timur, Jatiasih, Medan Satria, Mustika Jaya, Pondok Melati, dan Kecamatan Rawa Lumbu merupakan kategori kurang mengikuti standar K3. Wilayah yang termasuk ke dalam kategori ini yaitu yang hanya menerapkan 1 dari 4 standar yang dipersyaratkan. Persebaran spasial kategori Zonasi sentra-Zonasi sentra pengembangan UMKM Di Kota Bekasi disajikan pada Gambar 8.

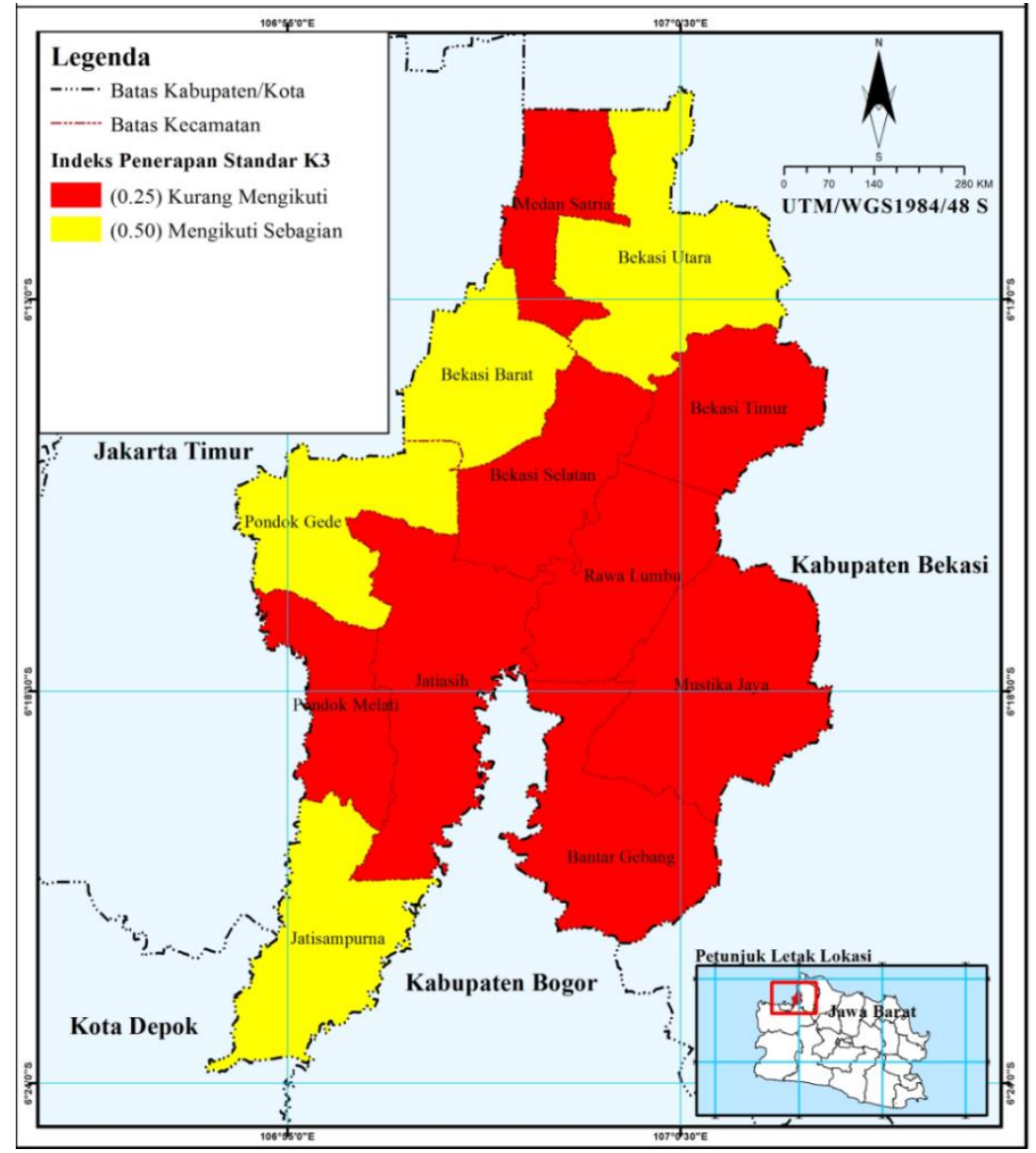

Gambar 8. Index K3 UMKM 
Tabel 7. Indeks K3 UMKM

\begin{tabular}{|c|c|c|c|c|c|c|c|}
\hline \multirow{2}{*}{ No. } & \multirow{2}{*}{ Kecamatan } & \multirow{2}{*}{$\begin{array}{l}\text { Rata-rata } \\
\text { penerapan } \\
\text { standar } \\
\text { K3 }\end{array}$} & \multirow{2}{*}{$\begin{array}{l}\text { Jumlah } \\
\text { dalam } \\
\text { Kecamatan }\end{array}$} & \multirow{2}{*}{ Kategori } & \multicolumn{3}{|c|}{ Luas } \\
\hline & & & & & $\mathrm{In}$ & ha & $\%$ \\
\hline 1 & $\begin{array}{l}\text { Bantar } \\
\text { Gebang } \\
\text { Bekasi }\end{array}$ & 1 & 4 & Kurang Mengikuti Standar K3 & 0,25 & 2.037 & 9 \\
\hline 2 & Selatan & 1 & 4 & Kurang Mengikuti Standar K3 & 0,25 & 1.538 & 7 \\
\hline 3 & Bekasi Timur & 1 & 4 & Kurang Mengikuti Standar K3 & 0,25 & 1.484 & 7 \\
\hline 4 & Jatiasih & 1 & 4 & Kurang Mengikuti Standar K3 & 0,25 & 2.570 & 12 \\
\hline 5 & Medan Satria & 1 & 4 & Kurang Mengikuti Standar K3 & 0,25 & 1.095 & 5 \\
\hline 6 & $\begin{array}{l}\text { Mustika Jaya } \\
\text { Pondok }\end{array}$ & 1 & 4 & Kurang Mengikuti Standar K3 & 0,25 & 2.672 & 12 \\
\hline 7 & Melati & 1 & 4 & Kurang Mengikuti Standar K3 & 0,25 & 1.178 & 5 \\
\hline 8 & Rawa Lumbu & 1 & 4 & Kurang Mengikuti Standar K3 & 0,25 & 1.710 & 8 \\
\hline \multicolumn{4}{|c|}{ Jumlah } & & & 14.285 & 66 \\
\hline 9 & Bekasi Barat & 2 & 4 & $\begin{array}{l}\text { Mengikuti Sebagian Standar } \\
\text { K3 } \\
\text { Mengikuti Sebagian Standar }\end{array}$ & 0,50 & 1.403 & 6 \\
\hline 10 & Bekasi Utara & 2 & 4 & $\begin{array}{l}\text { K3 } \\
\text { Mengikuti Sebagian Standar }\end{array}$ & 0,50 & 2.467 & 11 \\
\hline 11 & Jatisampurna & 2 & 4 & $\begin{array}{l}\text { K3 } \\
\text { Mengikuti Sebagian Standar }\end{array}$ & 0,50 & 1.869 & 9 \\
\hline 12 & Pondok Gede & 2 & 4 & K3 & 0,50 & 1.659 & 8 \\
\hline \multicolumn{5}{|c|}{ Jumlah } & & 7.399 & 34 \\
\hline \multicolumn{5}{|c|}{ Jumlah Keseluruhan } & & 21.684 & 100 \\
\hline
\end{tabular}

Hasil analisis zona sentra pengembangan menghasilkan 3 kategori zona sentra pengembangan meliputi zona sentra pengembangan 1 , zona sentra pengembangan 2 , dan zona sentra pengembangan 3 [Tabel 8]. Zona sentra pengembangan 1 memiliki nilai indeks sebesar > 0.14 dengan luas sebesar 5,842 ha atau $27 \%$ dari luas wilayah Kota Bekasi, secara kewilayahan Kecamatan Bekasi Barat, Jatiasih, dan Kecamatan Jatisampurna yang termasuk dalam kategori ini. Kategori zona sentra pengembangan 1 relatif sudah mampu mandiri dan memiliki kemampuan untuk berkembang.

Kategori zona sentra pengembangan 2 berada pada kualitas sedang dalam hal mendukung perkembangan serta pemusatan aktivitas industri UMKM pengolah makanan di Kota Bekasi. Persebaran spasial kategori zona sentra-sentra pengembangan UMKM pengolah makanan di Kota Bekasi disajikan pada Gambar 9.

Zona sentra pengembangan 3 memiliki luas sebesar 9,442 ha (44\%). Secara kewilayahan Kecamatan Bantar Gebang, Bekasi Selatan, Bekasi Timur, Mustika Jaya, dan Kecamatan Rawa Lumbu termasuk dalam kategori ini. Kategori Zonasi sentra pengembangan 3 berada pada kualitas rendah dalam hal mendukung perkembangan serta pemusatan aktivitas industri UMKM pengolah makanan di Kota Bekasi. 


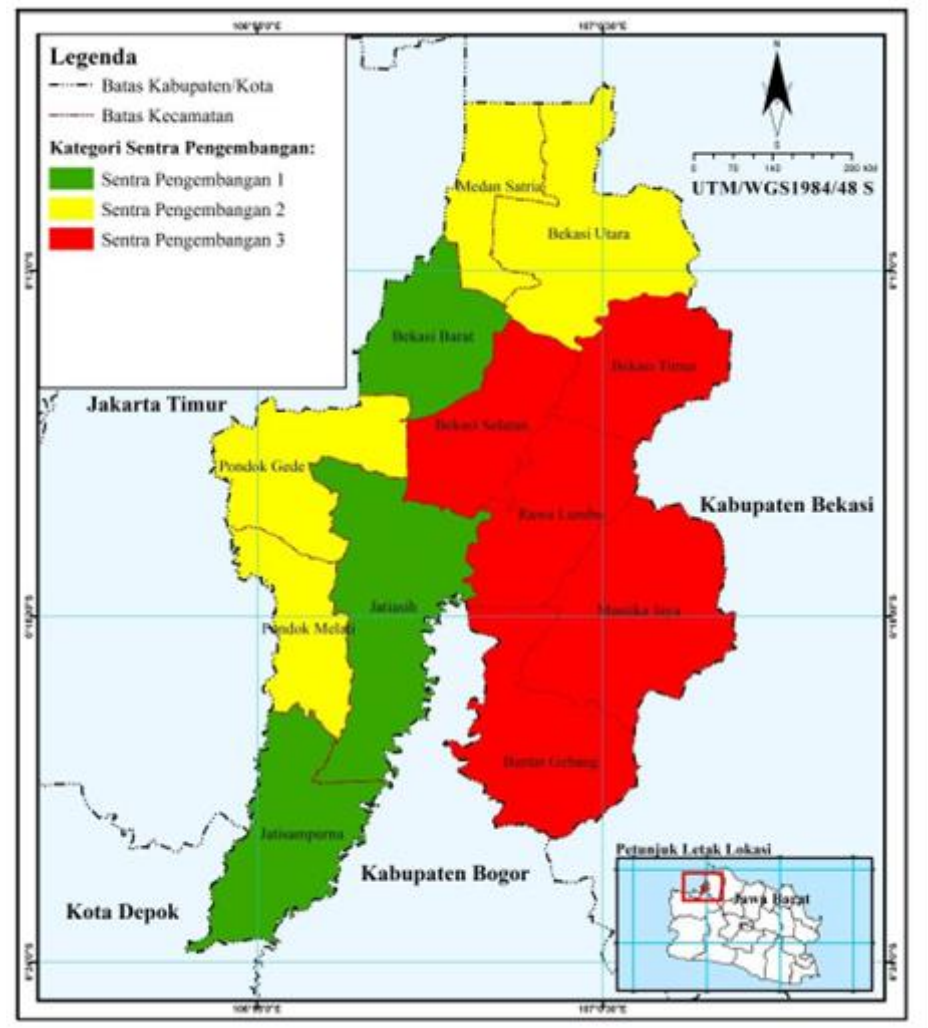

Gambar 9. Persebaran spasial kategori sentra-sentra pengembangan UMKM

Tabel 8. Sentra wilayah pengembangan UMKM

\begin{tabular}{|c|c|c|c|c|}
\hline \multirow{2}{*}{ Sentra Pengembangan } & \multirow{2}{*}{ Indeks } & \multirow{2}{*}{ Kecamatan } & \multicolumn{2}{|l|}{ Luas } \\
\hline & & & ha & $\%$ \\
\hline \multirow{3}{*}{ Sentra Pengembangan 1} & 0.16 & Bekasi Barat & 1,403 & 6 \\
\hline & 0.15 & Jatiasih & 2,570 & 12 \\
\hline & 0,16 & Jatisampurna & 1,869 & 9 \\
\hline Jumlah & & & 5,842 & 27 \\
\hline \multirow{4}{*}{ Sentra Pengembangan 2} & 0.12 & Bekasi Utara & 2,467 & 11 \\
\hline & 0.12 & Medan Satria & 1,095 & 5 \\
\hline & 0.12 & Pondok Gede & 1,659 & 8 \\
\hline & 0.13 & Pondok Melati & 1,178 & 5 \\
\hline Jumlah & & & 6,400 & 30 \\
\hline \multirow{5}{*}{ Sentra Pengembangan 3} & 0.10 & Bantar Gebang & 2,037 & 9 \\
\hline & 0.09 & Bekasi Selatan & 1,538 & 7 \\
\hline & 0.08 & Bekasi Timur & 1,484 & 7 \\
\hline & 0.09 & Mustika Jaya & 2,672 & 12 \\
\hline & 0.09 & Rawa Lumbu & 1,710 & 8 \\
\hline Jumlah & & & 9,442 & 44 \\
\hline Jumlah Keseluruhan & & & 21,684 & 100 \\
\hline
\end{tabular}

\section{KESIMPULAN DAN SARAN}

Jumlah UMKM terpilih sebanyak 220 sampel, dengan UMKM terbanyak terdapat yaitu di Kecamatan Pondok Gede (32 UMKM), Kecamatan Bekasi Selatan (29 UMKM), dan Kecamatan Bekasi Timur (26 UMKM). Hasil analisis zona sentra pengembangan menghasilkan 3 kategori zona sentra pengembangan dengan kategori zona sentra pengembangan 1 merupakan zona sentra terbaik yang memiliki kemampuan yang lebih besar untuk berkembang. Zona sentra pengembangan 1 dapat direkomendasikan menjadi kawasan UMKM digital untuk meningkatkan penjualan melalui pemasaran online (go digital) dengan cara meningkatkan pengetahuan dan keterampilan dalam aspek higienis dalam meningkatkan kualitas produk sehingga 
memenuhi standar kelayakan untuk dapat dipasarkan.

Diharapkan pemerintah memfasilitasi pelaku UMKM yang memiliki produk berkualitas dan peluang export dalam penyelenggaraan pameran internasional dengan menyediakan kios bagi UMKM. Namun, pemerintah juga harus meningkatkan pengawasan terhadap pemanfaatan lahan dengan melakukan relokasi kawasan yang digunakan UMKM sebagai tempat tinggal sekaligus tempat produksi sehingga masyarakat tidak dengan mudah memperoleh dan menggunakan lahan tersebut untuk kegiatan usaha.

\section{UCAPAN TERIMA KASIH}

Ucapan terima kasih penulis sampaikan kepada Pusat Pembinaan, Pendidikan dan Pelatihan Perencanaan (Pusbindiklatren)Bappenas RI selaku pemberi dana penelitian.

\section{DAFTAR PUSTAKA}

Adhadika, T. \& Pujiyono, A. (2014). Analisis Faktor-faktor yang Mempengaruhi Produktivitas Tenaga Kerja Industri Pengolahan di Kota Semarang (Studi Kecamatan Tambalang dan Kecamatan Gunung Pati). Diponegoro Journal of Economics, 3 (1), 1-13.

Andriani, G. N., Ardiansyah, L. O., Sulistio, H., \& Wicaksono, A. (2016). Kajian Lokasi Halte dan Jam Operasi Angkutan Kota Malang Berdasarkan SPM 2015 (Studi Kasus: Trayek LDH, AH dan ADL). Jurnal Mahasiswa Jurusan Teknik Sipil, 1 (2), 110-119

Claudia, C.A. (2017). Analisis Spesialisasi dan Konsentrasi Spasial Industri Manufaktur di Indonesia Tahun 2007-2013. Jurnal Ilmu Ekonomi, 1 (2), 225-239.

Harsono, H. (2015). Fasilitas Peranan Sarana dan Prasarana terhadap Produktivitas Kerja UKM di Kota Magelang. Jurnal Bina Praja: Journal of Home Affairs Governance, 4 (4), 237-242.
Hidayah, A., Paharuddin, P. \& Massinai, M. A. (2017). Analisis Rawan Bencana Longsor Menggunakan Metode AHP (Analiytical Hierarchy Process) di Kabupaten Toraja Utara. Jurnal Geocelebes, 1 (1), 1-4.

Kusmayanti, D. K. \& Tyas, W. P. (2016). Kajian perkembangan kawasan akibat keberadaan UMKM berbasis rumah (HBE) Pengolah Pangan Tradisional Getuk 'Kethek; satu rasa, Kota Salatiga. Jurnal Pengembangan Kota, 4 (2), 160168.

Marimin, M. \& Maghfiroh, N. (2010). Aplikasi Teknik Pengambil Keputusan dalam Manajemen Rantai Pasok. IPB Press.

Narimawati, U. (2007). Riset Manajemen Sumber Daya Manusia: Aplikasi Contoh \& Perhitungannya. Agung Media.

Prasetio, R. T. (2014). Inventory Control Using Statistics Forecasting on Manufacture Company. Jurnal Informatika, 2 (2), 136-142.

Pratomo, A. J. (2009). Analisis Kerentanan Banjir di Daerah Aliran Sungai Sengkarang Kabupaten Pekalongan Provinsi Jawa Tengah dengan Bantuan Sistem Informasi Geografis. Thesis. Universitas Muhammadiyah.

Rifa'I, B. (2013). Efektivitas Pemberdayaan Usaha Mikro Kecil dan Menengah (UMKM) Krupuk Ikan dalam Program Pengembangan Labsite Pemberdayaan Masyarakat Desa Kedung Rejo Kecamatan Jabon Kabupaten Sidoarjo, Kebijakan dan Manajemen Publik, 1 (1), 130-136.

Rizki, D. A., Rustiadi, E. \& Soma, S. (2017). Penentuan Pusat-pusat Kegiatan Baru sebagai Alternatif untuk Mengurangi Kemacetan Kota Bogor. Journal of Regional and Rural Development Planning (Jurnal Perencanaan Pembangunan Wilayah dan Perdesaan), 1 (3), 287-297.

Saaty, T. L. (1993). Pengambilan Keputusan Bagi Para Pemimpin. Pustaka Binama Pressindo. 
Santosa, S., Rustiadi, E., Mulyanto, B., Murtilaksono, K., Widiatmaka, W. \& Rachman, N. F. (2014). Pemodelan Penetapan Lahan Sawah Berkelanjutan Berbasis Regresi Logistik dan Evaluasi Lahan Multikriteria di Kabupaten Sukabumi. Majalah Globe, 16 (2), 176185.

Setiawan, A. H. (2010). Analisis Penyerapan Tenaga Kerja Sektor Usaha Kecil dan Menengah (UKM) di Kota Semarang. JEJAK: Jurnal Ekonomi dan Kebijakan, 3 (1), 39-47.

Setyanto, A. R., Samodra, B.R. \& Pratama, Y. P. (2015). Kajian Strategi Pemberdayaan UMKM dalam Menghadapi Perdagangan Bebas Kawasan ASEAN (Studi Kasus Kampung Batik Laweyan). Etikonomi, 14 (2), 205-220.

Sudarno, S. (2011). Kontribusi Usaha Mikro, Kecil dan Menengah (UMKM) dalam Penyerapan Tenaga Kerja di Depok. Jurnal Ekonomi dan Bisnis, 10 (2), 139146.

Suriani, S., Djafar, M. \& Saleh, F. (2019). Pemetaan Lahan Kritis dengan Metode Multi Criteria Evaluation di Sub DAS Amohalo. Jurnal Geografi Aplikasi dan Teknologi, 3 (1), 7-16.

Umar, I., Widiatmaka, W., Pramudya, B. \& Barus, B. (2017). Evaluasi Kesesuaian Lahan untuk Kawasan Permukiman dengan Metode Multi Criteria Evaluation Di Kota Padang. Jurnal Pengelolaan Sumberdaya Alam dan Lingkungan (Journal of Natural Resources and Environmental Management), 7 (2), 148154.

Yusuf, D. T. C., Santoso, I. \& Ikasari, D. M. (2018). Sugar Manufacturing Process: risk analysis and mitigation using fuzzy fmea and fuzzy ahp method. Bioscience Research,15 (3), 1575-1582. 